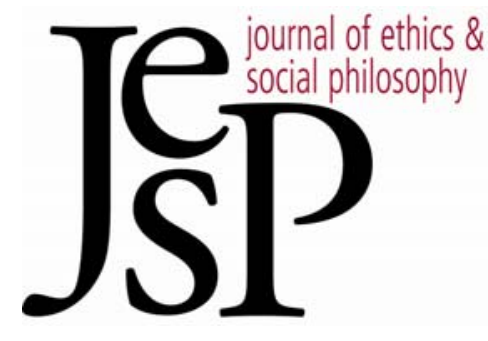

DISCUSSION NOTE

\title{
Practical knowledge and Foreseen Side Effects
}

By Niels VAn Miltenburg

Journal OF ETHICs \& Social PHILOSOPHY

Discussion NOTE | JANUARY 2012

URL: WWW.JESP.ORG

COPYRIGHT @ NIELS VAN MILTENBURG 2012 


\title{
Practical Knowledge and Foreseen Side Effects
}

\author{
Niels van Miltenburg
}

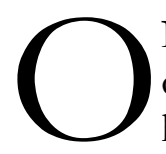

N ANSCOMBE'S VIEW, INTENTIONAL ACTIONS are characterized by a specific type of knowledge (practical knowledge) possessed by the agents that perform them. Recently, interest in Anscombean action theory has been renewed. ${ }^{1} \mathrm{Sa}$ rah Paul argues that Anscombean action theory faces a serious problem: It fails to discriminate between an action's intended aim or purpose and its foreseen side effects. Since Anscombeans conceive practical knowledge as the formal cause of intentional actions, Paul dubs this a problem of "deviant formal causation." In this paper I will show that Anscombean action theory can escape Paul's critique by employing a sufficiently developed conception of practical knowledge. It will turn out that Anscombeans can precisely capture the difference between intended aim and foreseen side effect in terms of differences in the agent's knowledge.

\section{Knowledge Without Observation}

Anscombe famously argued that agents who act intentionally can respond to questions of the form, "Why are you A-ing?" with answers like, "Because I am B-ing." But when questioned about their unintentional bodily movements they will respond with such answers as: "I wasn't aware I was doing that." 2 The difference between intentional and unintentional action is that when a movement is intentional the agent knows what she is doing.

Anscombe argues that such knowledge is without observation because we do not first have to look in order to know what action we are performing. When I am walking to the kitchen I do not have to wait and see whether I am taking rice or spaghetti out of the cupboard in order to know whether I am cooking risotto or pasta. I already know what $\mathrm{I}$ am doing because it is my intention in going to the kitchen. Compare this to a case of unintentionally stepping on someone's toe in a crowded bus. Here, we feel that we step on an uneven surface and realize that we stepped on someone's toe.

A large part of Intention is devoted to pinning down the peculiarities of the particular type of knowledge without observation that agents have of their own intentional actions, i.e., practical knowledge. Below I argue that by paying heed to some of those peculiarities, the Anscombean can meet Paul's challenge. But for now the stage is set to show the force of Paul's argument.

\footnotetext{
${ }^{1}$ See for instance: Thompson (2008) and Ford, Hornsby and Stout, eds. (2011). As Paul (2011) explains, this renewed interest is due to the fact that neo-Anscombean theories are believed to circumvent the problem of deviant causal chains that so plague the standard Davidsonian view.

2 Anscombe (1963), §6.
} 


\section{Paul's Challenge}

Paul sketches two scenarios, culled from an example by Anscombe 3 in which different gardeners go through the same movements of pumping and replenishing a house's water supply with poisoned water. Both gardeners have different purposes. The first acts with murderous intent, while the second is indifferent about the potentially deadly side effects of his action and merely wants to earn his pay. Even though both gardeners make the same movements, it would be wrong to say that both Murderous and Indifferent Gardener performed the same intentional actions. ${ }^{4}$

Paul rightly stresses that action theory should account for this difference between the two actions. Moreover, since the two scenarios are set up in a way that holds fixed many of the possible different grounds for a distinction (equal contexts, the same physical movements), "it seems that the asymmetry can only be traced to the divergent psychological properties of the two gardeners." 5

If Anscombe is right in thinking that an agent's nonobservational knowledge is the sole determinant of what one is intentionally doing, then we need to spell out this asymmetry in terms of a difference in both gardeners' nonobservational knowledge. According to Paul, this is impossible because both gardeners possess the exact same nonobservational knowledge. Both knew beforehand that the water was poisoned and that the inhabitants would drink water from their cistern. Therefore both gardeners know without observation that they are poisoning the inhabitants. Hence, Indifferent Gardener's knowledge deviantly turns his action into an intentional poisoning. ${ }^{6}$ Thus, the Anscombean cannot distinguish between aim and foreseen side effect.?

\section{An Anscombean Response}

Paul's argument hinges on a failure to recognize that nonobservational knowledge is a genus that allows different species. It is precisely by exploiting the different species of nonobservational knowledge that the Anscombean can distinguish intended aim from foreseen but unintended side effect.

As we saw above, when an agent acts intentionally she can answer "why" questions about her actions. She can explain why she walks to the kitchen and gets the rice out of the cupboard by pointing out that she is making risotto. Moreover, she does all these things because she knows she is making risotto and that these steps are perfectly

\footnotetext{
${ }^{3}$ Ibid., $\$ 25$.

4 Paul (2011): 11.

5 Ibid.: 11.

6 This is analogous to the well-known problem of deviant causation for causal action theory: Actions that are evidently unintentional come out as intentional due to their (deviant) causal history.

${ }^{7}$ Ibid.: 12 .
} 
fine means for risotto making - it isn't as if the agent observes her doings and then concludes that she, apparently, is making risotto. Furthermore, it is because the agent knows that she is making risotto that her walking to the kitchen is a part of risotto making. Thus this knowledge of means and ends unifies the agent's doings into one intentional action: Her knowledge gives the action its teleological structure. Hence the thought that practical knowledge is "the cause of what it understands." 8

At this point it is easy to misunderstand the (formal) causal role of practical knowledge. One might think that practical knowledge merely unifies a series of otherwise random events that would have happened anyway. On this view, even if the agent did not know that she was making risotto she still could have walked to the kitchen, grabbed some rice and eventually plated up something risotto-like we just wouldn't have been able to collectively describe her actions as an intentional risotto making. The Anscombean idea, however, is that the agent brings about the sequence of events only because she views them as means to the action she knows she is performing. Practical knowledge is the driving force behind intentional action. We constantly correct our movements, for instance, when we steer our hands towards a doorknob, and we do so because we know we are opening a door. ${ }^{9}$

It follows that nonobservational knowledge is practical only when it plays a specific role in the coming about of the action that it represents. But if this is so then, even though both gardeners might know the same things nonobservationally, the two gardeners do not have the same practical knowledge. Paul writes:

If it is necessary and sufficient for the formal causation of an intentional poisoning that the agent know he is bringing about a poisoning in virtue of the practical efficacy of that very bit of knowledge, the poisoning comes out as intended in the case of the Indifferent Gardener as well as the Murderous Gardener. ${ }^{10}$

Thus, Paul claims that the knowledge of both Murderous and Indifferent Gardener is equally practically efficacious. But this is simply false. Indifferent Gardener's knowledge that he is poisoning is not efficacious. If Indifferent Gardener had been ignorant of the fact that the water was poisoned and thus hadn't known that his replenishing would bring about the poisoning, he would still have replenished the

\footnotetext{
8 Anscombe (1963), §48.

9 The productive role of practical knowledge becomes even more apparent if we consider cases in which it is suddenly absent. For example, an agent is walking down Fifth Avenue, forgets what she is doing and stops walking. It is only after she remembers that she was, say, buying some groceries that she is able to continue on her way. See Velleman (1989): 15.

10 Paul (2011): 12. Paul seems to introduce an additional condition for the formal causation of an action by the agent's knowledge, namely that the agent must know of her knowledge that it is efficacious, but to me it seems that an Anscombean does not need to endorse this further condition.
} 
water supply. Replenishing, after all, is a fine means to earning his salary. Compare this with Murderous Gardener. He would not have replenished if he hadn't known that it was a means to poisoning, since the point of his replenishing consists in killing the inhabitants. Hence Murderous Gardener's knowledge that he is poisoning clearly is practically efficacious, while Indifferent Gardener's knowledge is not. ${ }^{11}$

Thus the Anscombean is able after all to distinguish between the actions of both gardeners. She claims that an action inherits its form from the practical knowledge of the agent, and since both gardeners have different practical knowledge of their respective actions, the two actions are different. Murderous Gardener's action is an intentional poisoning, because he practically knows that he is poisoning. Indifferent Gardener's poisoning is not intentional because his (nonobservational) knowledge that the replenishing brings about a poisoning isn't practically efficacious. For him, the poisoning is merely a foreseen side effect.

\section{Two Objections}

Paul objects that it is question begging to deny that Indifferent Gardener's knowledge that he is poisoning the inhabitants is practical, i.e., to exclude it from his practical reasoning. After all, she argues, Indifferent Gardener knew full well that the water was poisoned and therefore makes his decision "in the light of his expectation that it will result in the poisoning $[\ldots]$ and a reconstruction of how he reached that decision ought to include that expectation." 12 This seems incorrect, at least on Anscombe's picture of practical reasoning. For her, practical reasoning is the deduction of means from ends with a view to action. ${ }^{13}$ An Anscombean would therefore say that the indifference of our gardener consists in his failure to treat his knowledge that the water is poisoned as a reason to refrain from pumping. Paul's argument unfairly presupposes a non-Anscombean account of practical reasoning. ${ }^{14}$ However, for now it is sufficient to notice that if we, like Paul, want to account for the difference between aim and foreseen side effect, the distinction must be grounded somewhere. The hypothesis that there is more than one kind of nonobservational knowledge is therefore no more question begging or ad hoc than Paul's own solution, viz. that there are mental states called "commitments."

Such commitments are mental states that cause intentional bodily movements, such that an action is an intentional A-ing when it is

\footnotetext{
11 Another way of seeing the difference in practical knowledge between the gardeners is by considering what would happen if the gardeners found out that the water wasn't poisoned after all. Indifferent Gardener would not care (as is characteristic of him), whereas Murderous Gardener's knowledge that he is poisoning the inhabitants would cause him to look for different means of doing so.

12 Paul (2011): 14.

13 Anscombe (1963), $₫ 33$

14 For an enlightening discussion of Anscombe's views on practical reason see Müller (1979).
} 
caused by a commitment to A. The action of Murderous Gardener is an intentional poisoning because his action is caused by his commitment to kill the inhabitants, whereas Indifferent Gardener's poisoning is not intentional but only a side effect because it is brought about by a different commitment. ${ }^{15}$

I think that this proposal is very unsatisfactory. What philosophy of action tries to understand is why certain results of an action are aimed for and others are mere side effect. In other words, we want to understand why agents are committed to some results and not to others. Just claiming that we are committed to some results because there are mental states called "commitments" that cause us to be so committed isn't much of an explanation at all. It instead seems a mere rephrasing of our original problem in terms of mental states. ${ }^{16}$ The Anscombean on the other hand makes the distinction between aim and side effect by claiming that both are known in different ways, which allows for an actual analysis, e.g.: nonobservational knowledge of side effects is deduced from the agent's practical knowledge and his general causal knowledge. This meshes nicely with the overall project of analyzing the intentionality of actions in terms of the kinds of knowledge possessed by the agent. ${ }^{17}$

Let us turn to a second objection. Paul thinks that the distinction between aims and foreseen side effects cannot be grounded in something that is knowledge-like at all:

As long as the representational relation between agent and action is held to be a cognitive, knowledge-apt representation, the foreseen side effects will not escape inclusion in the content of what is intended. ${ }^{18}$

Instead we should ground the distinction in mental attitudes that represent their content in a different way ("commitments," on her proposal):

What is of primary importance, though, is that it is an attitude that has a conative, world-to-mind direction of fit. It represents its content as to-bedone rather than being-done. ${ }^{19}$

\footnotetext{
15 Paul's idea is that these commitments can be isolated. Consider counterfactual scenarios like the one in which Murderous Gardener finds out that the water wasn't poisoned after all. In such a scenario his commitment to killing the inhabitants would dispose him to make an extra effort to put the poisoning back on track. Indifferent Gardener would lack this disposition because he is otherwise committed.

16 Of course this does not hold for all of causal action theory. Davidson, for example, tried to offer a proper analysis of intentional action in terms of the agent's beliefs and desires.

17 Anscombe herself already makes a distinction similar to the one discussed here: the distinction between intentional and voluntary doings. See Anscombe (1963), §49. Furthermore, she employs the distinction in her account of double effect, Anscombe (1982).

18 Paul (2011): 17.

${ }^{19}$ Ibid.: 18.
} 
This is indeed important, but Paul fails to recognize that practical knowledge has such a direction of fit. This is what distinguishes it from theoretical knowledge. ${ }^{20}$ It therefore represents its content as tobe-done. This comes out when we pay attention to the temporal extendedness of actions. You do not cook a risotto in an instant. As we saw in the previous section, it is the agent's knowledge of what she is doing that guides her through the different steps of risotto making. Thus the practical knowledge that represents risotto making as the aim of the ongoing action at the same time represents, e.g., the cutting of onions as the relevant next thing to be done.

\section{Conclusion}

Paul argues that the Anscombean lacks the means to distinguish between aim and foreseen side effect. On behalf of the Anscombean, I reply that aims are known practically instead of merely nonobservationally, thus providing criteria for the distinction. ${ }^{21}$

Niels van Miltenburg

Utrecht University

Department of Philosophy

niels.vanmiltenburg@phil.uu.nl

\section{References}

Anscombe, G. E. M. (2000/1963). Intention, second edition. Cambridge, MA: Harvard University Press

(1982). "Medallist's Address: Action, Intention and 'Double Effect." Proceedings of the American Catholic Philosophical Association 56: 12-25.

Ford, A., Hornsby, J. and Stoutland, F., eds. (2011). Essays on Anscombe's Intention. Cambridge, MA: Harvard University Press.

Müller, Anselm (1979). "How Theoretical Is Practical Reasoning?" In C. Diamond and J. Teichman, eds. Intention and Intentionality: Essays in Honor of G. E. M. Anscombe. Brighton: The Harvester Press.

Paul, Sarah (2011). "Deviant Formal Causation." Journal of Ethics and Social Philosophy 5(3).

Thompson, Michael (2008). Life and Action: Elementary Structures of Practice and Practical Thought. Cambridge, MA: Harvard University Press.

Velleman, J. David (1989). Practical Reflection. Princeton, NJ: Princeton University Press.

20 Anscombe (1963), §32.

${ }^{21}$ I am grateful to Dawa Ometto, Thomas Müller and Michael De for their comments. 